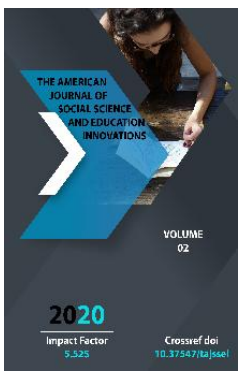

\title{
Role Of Irrigators In The Development Of Water Civilization
}

\author{
Rano Zafarjon Qizi Khatamova \\ Doctoral Student Of The Department Of “Humanities", Tashkent Institute Of Irrigation \\ Agricultural Mechanization Engineers, Tashkent, Uzbekistan
}

Journal Website:

http://usajournalshub.c

om/index,php/tajssei

Copyright: Original

content from this work

may be used under the

terms of the creative

commons attributes

4.0 licence.

\section{ABSTRACT}

The article discusses water-related civilizations, the irrigation thinking formed under their influence, the formation of centuries-old experience in the field of irrigation, mechanization of agriculture and land reclamation in the country, as well as the creation of the Tashkent Institute of Irrigation and Land Reclamation Engineers in the early twentieth century. briefly mentioned as one of the main reasons. It also gives a brief overview of the current educational process and the ongoing reforms of the institute.

\section{KEYWORDS}

Centuries-old traditions, spirituality, education and upbringing, irrigation and agriculture, Toshkent Institute of Irrigation and Agricultural Mechanization Engineers.

\section{INTRODUCTION}

It is no accident that our ancestors said: "The fate of the universe depends on water." Although the formation of new and modern values inherent in water civilization is today one of the most pressing problems, in fact, the worship of the elements of nature was first formed as primitive religious ideas, and then reflected in Zoroastrianism and other religious teachings. 
The history of the emergence of values and the first irrigation ideas inherent in the water civilization in Central Asia dates back thousands of years.

\section{MAIN RESULTS AND FINDINGS}

In this regard, in particular, the four elements of nature served not only in religious and philosophical worldviews, but also in the teachings of ancient and medieval thinkers as a starting point for understanding reality. For example, in ancient Greece, the founders of the school of Miletus saw Fales as water, Aniximenes as air, and Heraclitus as the sun and earth as the foundation of the universe. Or in the teachings of Abu Abdullah alKhwarizmi or Alisher Navoi, one of our ancestors who lived and worked in the Middle Ages, four elements were considered the foundations of nature. In fact, we see that the views on the four elements - "chorunsur" exist both in Avesto and in a number of world religions.

Avesto recognizes that not only man is sacred, but also a handful of soil, a breath of water and a breath of air. Particular attention is paid to respect and appreciation of water, which is the source of life. It depicts a special dedication in the symbol of Ardvisura (Amudarya). The waters of the Amudarya are the largest and most holy of all waters, and they are called "waters above the waters." Thus arose the tradition of preserving the river and combining the beauty of nature with water. According to Avesto, time and human life are directly related to "vast pastures, deep lakes, moist rivers, mountain meadows." As the earth nourishes man, water gives him bounty. That is why the Zoroastrians knew and respected the land planted with herbs and fruit trees, the land where the water was always smooth. Those who polluted the water and violated its conservation laws were punished. Since childhood, team members learned to plant trees, take care of them, plant greenery, plant gardens and not pollute canals and pools.

This work was considered not only as a necessity of luxury and life support, but also as a means of instilling the ideas of generosity, industriousness, spiritual perfection, creativity. Spitting in water, destroying crops, harming animals and birds, and also kindling fire were considered the main sins. Chapters 13-14 of Avesto Vendidat provide for forced labor if the water is not stored or polluted. ${ }^{1}$

One of the most important practical measures in the life of our rapidly developing country today is the combination of spiritual values, the high culture of our people, including traditional methods of managing the use and protection of nature with universal values.

At the same time, the spiritual development of people, especially youth, a global role in the balance of nature and society, the need to attract the attention of our country and the public to these issues in order to clearly define the tasks of educating future generations in an ecologically healthy environment.

Since time immemorial, in the eastern world, including Central Asia, especially among indigenous peoples, it has been very important to preserve and use the blessings of nature. Especially in our country, which has arid conditions, the culture of rational irrigated agriculture was formed due to the rational use of land and water.

\footnotetext{
${ }^{1}$ Bertels E. E. Otryvki iz Avesty // Sbornik

«Vostok». - Moskva: Gosizdat, 1924. B 4. p.75
} 
No wonder our scientists said: "It is better to return to Ointment." Indeed, the sense of remembering and not forgetting the past, the knowledge and conclusions obtained as a result of its study, are an important spiritual basis for fostering a sense of participation in today's life, its changes and innovations, radical reforms and responsibility for the future.

In this sense, it is important for every manager and employee, specialist and employee to know the history of the organization and the community in which he works, and to understand its importance, draw the right conclusions and learn from the events of different times and the actions of those who worked at that time. Because history is a great teacher, teacher who teaches the past, the foundation of today, the foundation of the future.

There are countless historical examples and evidence that confirm that such a conclusion was true. The traditions in this area, first of all, the existence of centuries of experience in our country under the influence of water-related civilizations, the conservation of land and water in Central Asia, which for thousands of years relied on irrigated agriculture, is the basis of life. is inextricably linked with the assessment of how.

Thus, from time immemorial in Central Asia, especially in the territory of modern Uzbekistan, irrigated agriculture has developed, and on the basis of the construction of hydraulic structures, a rich and remarkable experience of irrigation equipment has appeared. A special place in the history of irrigation in Uzbekistan belongs to the ancient hydraulic structures, which are material and cultural monuments created by our ancestors, preserved to this day.

It should be noted that the creation of the Tashkent Institute of Irrigation and Land Reclamation Engineers for the first time in Central Asia in Uzbekistan, in Tashkent, was a special time requirement. In the end, by the beginning of the twentieth century, the scale of irrigation, land reclamation and mechanization of agriculture throughout the region, especially in our country, was expanding, and the importance of work in this area was growing. This, in turn, necessitated the formation of a system of training mature personnel needed for the industry.

At the same time, the creation in our country of this institute, which is the first higher educational institution in the region to train qualified specialists in the field of irrigation, agricultural mechanization, and land reclamation, is undoubtedly a solid historical foundation and a unique result of centuries of experience. $^{2}$

In this regard, the main goal of the movement of many scientists was to free society of the early twentieth century, which formed the Tashkent Institute of Irrigation and Agricultural Mechanization Engineers, from medieval vices, cultural backwardness and colonial oppression, superstitions in order to lead people to modern development.

Our scientists and ancestors who lived at that time very well understood that the history and development of our people were an extremely important historical need for the educational needs of that period. They are

\footnotetext{
${ }^{2}$ Nazarov Q., Xamidov X. Etuk kadrlarini tayyorlash maskani. - Tashkent, 2019
} 
based on the traditions of the Avesta, developed in the Middle Ages by Farobi and Fergani, Beruni and Ulugbek, Navoi and Babur, and then Munis, Ogaha and Ahmad Donish, who knew the secrets of the mirab.

At the same time, there was a growing desire to transfer print, publishing, science, literature, culture and education to a national basis, which would facilitate the dissemination of such ideas. At the same time, secular knowledge, including irrigation, agriculture, and land reclamation, began to attract attention.

In this regard, the Jadid school system has gained importance, which subsequently played an important role in the establishment and development of higher education institutions, such as TIIAME. During these years, Behbudi textbooks and teaching aids, such as "Geography of Muntahabi" ("Brief General Geography”), “Madhali Geography of Umrani" ("Introduction to the Geography of the Population”), "Brief Geography of Russia" ("Brief Geography of Russia"), "Abdullah Avloni" Textbooks "School Geography" and "Problems of Accounting" also played an important role in the history of the development of domestic pedagogical thought, including the study of irrigation and land reclamation. ${ }^{3}$

In these books, magazines and newspapers published at that time, as well as in many other issues, special attention is paid to further improving the use of water and water resources in our country, raising the mechanization of agriculture to the level of modern requirements. We can say that the

\footnotetext{
${ }^{3}$ Irrigation in Uzbekistan. - Tashkent: 1975, p 26
}

schools created by the Jadids on the eve of the twentieth century and in its first years, became the basis for the creation of higher educational institutions in our country, which created the necessary opportunities for this.

Thanks to these principles, with the support of scholars such as Behbudi, Abdullah Avloni, Fitrat, Cholpon, Turkestan people's Dorulfun was created in April 1918, and Munarvarkori Abdirashidkhonov was elected its rector. Launched on June 2, 1918, this pharmacist focused on religious and secular knowledge, including informing the public about the secrets of natural phenomena and laws, irrigation, agriculture, and land reclamation.

In turn, all this indicates that on September 7, 1920, the former Soviet government decided to establish the Turkestan State University (TSU) in Tashkent. Among the 8 faculties of TSU, which in accordance with the conditions and requirements of the time was a large university, there were agricultural and engineering faculties, which later undoubtedly played an important role in the formation of TIIAME.

It should be noted that in this complex organizational process, it took several years for a higher education institution to train mature specialists in the field of irrigation, agricultural mechanization, and land reclamation. In this sense, TIIAME, the first higher educational institution in the region that trains mature specialists in these fields, has passed a certain path of formation and development since the beginning of the twentieth century.

It is known that at the end of the twentieth century, in 1991, in connection with the 
independence of our country and its development as an independent state, profound socio-economic, political, spiritual and educational changes took place in the life of the republic. Such significant changes and updates became the basis for the formation of a new era, a sharp turn in the life of TIIAME. During this period, the material-technical and educational base of the institute was further strengthened, the methods of training specialists were mastered, the system of teachers and teachers was improved, and the cultural and living conditions of students were improved.

During this period, the institute achieved the organization of the educational process in the state language, the transition to a two-level system of education (undergraduate and graduate programs), the creation of new generation disciplines. In order to ensure successful and high-quality implementation of the "National Training Program" by the Institute staff, special attention was paid to providing potential and competitive personnel in agriculture and water resources management, further strengthening the database. ${ }^{4}$

Currently, a well-coordinated team of professors, specialists, workers and employees is working at the institute. As of March 2018, the Institute has 484 professors and teachers in 549.25 full-time units (40 of them are doctors of science, 171 are candidates of science), 144 professors and teachers work part-time (21 of them are doctors of science, 38 are candidates'

\footnotetext{
${ }^{4}$ Nizomov A. Suv ta'minoti tarixida qadimgi gidrotexnika inshootlarini saqlashni davom ettirish to'g'risida // O'rta Osiyoning madaniy merosi to'g'risida. - Tashkent: UzNU, 2002 p23.
}

sciences). works. Scientific potential is $43.6 \%$ in the main state and $44.0 \%$ among peers. ${ }^{5}$

The Institute consists of 7 faculties (irrigation and drainage engineering, hydraulic engineering, mechanization of irrigation and drainage, agricultural mechanization, electrification and automation of agriculture and water management, land use and land cadaster, faculty of economics and management), master's program, 36 departments. 21 of them are specialized departments), a training and methodological department, an information and resource center, a center for environmental and geographical information systems, an information technology center, a department of spirituality and education and talented youth, a department of international relations, a monitoring and internal control department, a marketing department There is a department for working with academic lyceums, professional colleges and other departments.

Our dear Homeland, which annually celebrates more than a quarter of a century of independence, is extremely important with the beginning of a new stage in the life and work of the Tashkent Institute of Irrigation and Agricultural Mechanization Engineers. This stage began with the creation of the Tashkent Institute of Irrigation and Land Reclamation on the basis of the Decree of the President of the Republic of Uzbekistan dated May 24, 2017 No. PP-3003 “On measures to radically improve the training system for

\footnotetext{
${ }^{5}$ Nazarov Q., Xamidov X. Etuk kadrlarini tayyorlash maskani. - Tashkent, 2019
} 
engineers and technicians for agriculture and water management" ${ }^{\prime 6}$ we will tell the truth.

In accordance with the decree of the President, the agricultural sector should be provided with potential, competitive personnel, further strengthening of databases, training, an experimental process on the ground (dumps), farms, enterprises, and full provision of the educational process with advanced pedagogical technologies. One of the main tasks of the faculty and staff of the institute is to ensure full coverage of the computer information network connected to the information network, and the quality of other requirements.

In accordance with the Decree of the President of the Republic of Uzbekistan dated April 20, 2017 No. PP-2909 "On measures for the further development of the higher education system", state educational standards, qualification requirements, curricula for 25 undergraduate specialties and 23 masters were introduced and implemented by the institute and the programs were analyzed and revised in collaboration with experts from relevant ministries, departments, organizations, companies and enterprises, taking into account the needs of the sector. These revised documents were introduced from the 2017-2018 school year. Problematic lectures are systematically organized for leading and experienced specialists from employers, students and teachers on modern technologies and technologies in production, innovative innovations in specialized departments.

\footnotetext{
${ }^{6}$ https://lex.uz/m/acts/3222090
}

The Institute has developed the "Program of action strategy for 2017-2021 in five priority areas of development of our country". The TIIAME Action Strategy Program provides for the training of pedagogical, methodological, spiritual and educational, scientific and scientific-pedagogical personnel, the development of international relations and public works, i.e. efficient use of land and water resources, hydraulic and water bodies, as well as land reclamation and agricultural machinery in the country. serves to fulfill its strategic tasks of training highly qualified specialists with competent, mature and broad capabilities that ensure sustainability, development and security. ${ }^{7}$

\section{RESULTS}

In this regard, all of the above clearly proves that TIIAMEirrig, the first higher education institution in Central Asia in the field of irrigation and agricultural mechanization, has a historically solid foundation. This, in turn, indicates the need to rely on historical foundations when studying the stages of the institution's establishment and development, and on the other hand, important aspects and priorities of today's activities provide a solid basis for understanding the essence of current tasks. At the same time, we must not forget that today's requirements for the education of the young generation with high spirituality and modern thinking in this regard impose a huge responsibility on each of us.

This, in turn, made it possible, on the one hand, to show the formation of people with

\footnotetext{
${ }^{7}$ Nazarov Q., Xamidov X. Etuk kadrlarini tayyorlash maskani. - Tashkent, 2019
} 
Doi: https://doi.org/10.37547/tajssei/Volume02Issue08-13

local irrigation thinking and the need to rely on historical foundations when studying the stages of improving this process. On the other hand, this approach helps to identify important aspects and priorities of today's activities in this area, to understand the essence of current tasks in this area. ${ }^{8}$

\section{REFERENCES}

1. Decree of the President of the Republic of Uzbekistan dated May 27, 2017 No. PP-3003 "On measures to radically improve the system of training engineers and technicians for agriculture and water management"

2. https://lex.uz/m/acts/3222090

3. Bertels Ye. E. Excerpts from the Avesta // Collection "East". - Moscow: Gosizdat, 1924

4. Nazarov Q., Khamidov X. "Etuk kadrlarini tayyorlash maskani”. - Tashkent, 2019

5. Irrigation in Uzbekistan. - Tashkent: Fan, 1975

6. Nizomov A. "Suv ta'minoti tarixida qadimgi gidrotexnika inshootlarini saqlashni davom ettirish to'g'risida // O'rta Osiyoning madaniy merosi to'g'risida." - Tashkent: UzNU, 2002

7. Mineralno-syrevye resursy Uzbekistana / Pod red. X. T. Tulyaganova. Tashkent: 19

\footnotetext{
${ }^{8}$ Mineralno-syrevye resursy Uzbekistana / Pod red. X. T. Tulyaganova. Tashkent: 1978. - Ch. I. p 93
} 